\title{
Cultural Adaptation of the National Institutes of Health - Chronic Prostatitis Symptom Index (NIH-CPSI) - to Brazilian Spoken Portuguese: NIH-CPSI (Braz)
}

\author{
Cristiano Novotny, Eduardo Deves, Rodrigo Novotny, Igor Kunze Rodrigues, Fabrício Souza Neves
}

Federal University of Santa Catarina, Brazil

\section{ABSTRACT}

Objectives: To create a Brazilian version of the National Institutes of Health - Chronic Prostatitis Symptom Index (NIH-CPSI) using a cross-cultural adaptation process.

Materials and Methods: The nine items of the NIH-CPSI were translated to Portuguese, by two independent translators, of native Portuguese language origin, and it was obtained a single version, that was retranslated to English by two English native spoken translators, in order to correct any discrepancies. Those versions were compared to the original text, the modifications were applied and it was created a final version in Portuguese. That was pre-tested and applied to 30 patients with pain or perineal or ejaculatory disorder. To each item of the pre-final version it was assigned a score according to the grade of understanding and clarity in order to implement the adequate corrections. The final version in Portuguese was submitted to evaluations including face validation and psychometric proprieties of reproducibility and internal consistency, respectively evaluated by the (p) Pearson correlation coefficient and $\alpha$ Cronbach coefficient.

Results: All items applied to 30 patients during pre-test phase had a grade higher than 8 of understanding and clarity, and were considered clearly understandable by the patients. However, at face validation evaluation, there was an inconsistency of item three that was redone. The final produced version, called NIH-CPSI (Braz) showed good reproducibility ( $\mathrm{p}=0.89-0.99)$ and internal consistency ( $\alpha$ Cronbach coefficient $=0.85-0.93$ ).

Conclusions: NIH-CPSI was adapted to Brazilian spoken Portuguese and its original proprieties were maintained, being a valid instrument for evaluations of symptoms of chronic prostatitis in Brazilian patients.

\section{ARTICLE INFO}

\section{Key words:}

Prostatitis; Diagnosis; Lower Urinary Tract Symptoms

Int Braz J Urol. 2013; 39: 683-91

Submitted for publication: January 30, 2013

Accepted after revision: August 15, 2013

\section{INTRODUCTION}

Many urological consults refer to symptoms of chronic prostatitis/chronic pelvic pain syndrome (CP/CPPS). Those are very frequent diagnosis in men less than 50 years old with a significant impact of quality of life (1). According to the National Institutes of Health (NIH) (2), there are four categories of prostatitis. CP/CPPS is type III, and includes IIIA (inflammatory) and IIIB (non- -inflammatory), and represents most cases. This category (III) also presents a challenging diagnosis, has several symptoms and no pathognominic clinical finding (1). It presents chronic pelvic pain, associated to micturition disorders, psychological aspects and impact on quality of life of patients. It has high prevalence with a global rate of $8.2 \%$ (3). Laboratorial evaluation using Meares-Stamey diagnostic tests is complex (4), not sensible to non-inflammatory chronic prostatitis (5) and not 
easily reproducible in clinical practice (6). Laboratory findings are non-specific and clinical history is important to diagnosis. It is important the use a valid instrument for correct diagnosis, follow-up and evaluation of treatment.

Several symptomatic index for prostatitis were developed, most of them not validated scientifically $(7,8)$. Only the National Institutes of Health (NIH) Chronic Prostatitis Collaborative Research Network produced a valid instrument for evaluation of symptoms of CP/CPPS: the NIH - Chronic Prostatitis Symptom Index (NIH-CPSI) (9). It has nine items, divided in three domains (pain, urinary symptoms and quality of life) and it is used as diagnostic tool for the diagnosis and follow-up of $\mathrm{CP} / \mathrm{CPPS}$. Initially it was presented in English, but it was adapted to Spanish (10), Japanese (11), German (12), Italian (13), Estonian (14), Malay (15), Finnish (16), and French (17). However, it was not adapted to Brazilian spoken Portuguese until now. Our goal was to create a Brazilian version of the NIH-CPSI, using a cross-cultural process based on the north-American version.

\section{MATERIALS AND METHODS}

\section{NIH-CPSI description}

NIH-CPSI (Figure-1) includes the main urinary symptoms related to $\mathrm{CP} / \mathrm{CPPS}$ with a final score 0-43, divided in three domains: pain or discomfort (4 items, with a total score of 0-21), urinary symptoms (2 items, with a total score of 0-10 points), and impact of quality of life (3 items, with a total score of 0-12 points) (9).

Patients with pain or perineal or ejaculatory discomfort with NIH-CPSA score $\geq 4$ are considered with symptoms of CP/CPPS. Those with pain or perineal or ejaculatory discomfort and score $\geq 8$ are considered as patients with CP/CPPS moderate to severe (18). The higher the score, more important is the impact of symptoms.

\section{Cross-cultural adaptation}

For the process of cross-cultural adaptation, it was followed the "Guidelines of Institute for Work and Health" (19) after authorization of the author. Initially the NIH-CPSI was translated to Portuguese by two independent bilingual native spoken Portu- guese translators: an urologist physician (T1) and a non-medical translator without knowledge on the subject (T2). A second phase, mediated by a native Portuguese spoken mediator, included comparison and summarization of both translations, producing a single consensual version called T12. From T12, two different back-translations were performed by English, by two independent English native spoken non-medical translators (BT1 and BT2). In a next phase, a panel of specialists, including all translators, Portuguese and English teachers and a moderator evaluated all reported data, solved any discrepancies and created a pre-final version of the questionnaire.

\section{Pre-Test}

Pre-final version was submitted to pre-test. At this phase, the version was submitted to 30 consecutive patients that spontaneously attended the Urologic Service of the University Hospital of Universidade Federal de Santa Catarina (UFSC) with pain or perineal or ejaculatory discomfort as the main complains. The exclusion criteria included illiterate patients or those with cognitive deficit that prevented reading and understanding the instrument and those who refused to participate on the project. All patients were informed about the observational characteristic of the study, without any immediate benefit and that the result would be useful for the diagnosis and follow-up of CP/CPPS in the future. At pre-final version, after each of the nine translated items of NIH-CPSI it was included a table in order to the patients score each item, from 1 to 10 , according to their grade of understanding and clarity. The translated questions scored 1 to 4 were considered confusing, those 5 to 7 with low understanding and those with 8 to 10 were considered understandable.

Test

The final Portuguese version of NIH-CPSI, that included all modifications suggested during the evaluation of the pre-final version, was applied to other 30 consecutive patients that attended spontaneously the Urological Department of the University Hospital of UFSC with pain or perineal or ejaculatory discomfort. The exclusion criteria again included illiterate patients or those with cognitive deficit that prevented them to understand and read the instrument or that refused to participate on the project. 
Figure 1 - National Institutes of Health Chronic Prostatits Symptom Index (NIH-CPSI). Adapted from: (9) Litwin et al., J Urol 1999; 162, p.374, permission of Elsevier.

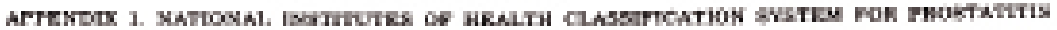

\begin{tabular}{|c|c|c|}
\hline Type & Clawaificatien & Dvfiation \\
\hline I & Arute hacterial proetmetitio & Bvidenon of acute towterial infection \\
\hline II & Chroesc besterial prostatitis & Evidenoe of rearrent buctetial infection \\
\hline III: & $\begin{array}{l}\text { Chrowik abacterial peostetitis } \\
\text { ichroedic pelvie pain syodromel }\end{array}$ & No dencestrable infetion \\
\hline $\mathbf{A}$ & Infonmatery & 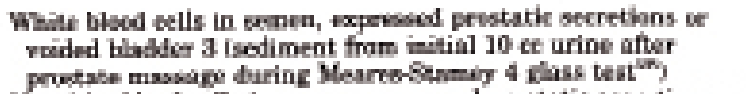 \\
\hline $\mathbf{B}$ & Naninflammatory & 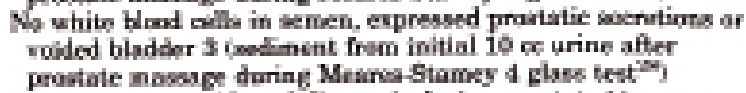 \\
\hline IN & Asympeematic inflummatery prostatitis & 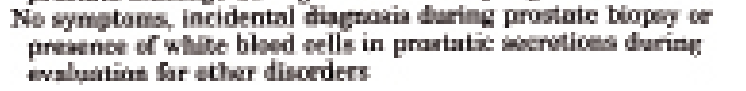 \\
\hline
\end{tabular}

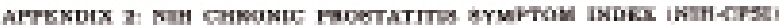

Pain ar Disoomfert

1. In the lnot week. have you experienced any pain or dis. conburt in the folbowing areas?

a. Area between rectues and testicles Iperineme!

b. Thoticles

c. Tip of the penis ince related to erination!

d. Below sour waist, in your pubie of bladder area.

2. In the laet week, have you experienoed

a. Pain ec burning during urinatian?

D. Poin ee disoombart during ar after seruial climax (ejibodationi?

$\begin{array}{cc}\text { Yes } & \text { No } \\ \square_{1} & \square_{0} \\ \square_{1} & \square_{0} \\ a_{2} & a_{0} \\ a_{2} & \square_{0}\end{array}$

3. How aften here you had pain er disomerort in any of these arees aver the last week?

D. Never

D, Rarly

D. Bartitimes

D. OAtnen

a. Drually

D. Always

4. Which number bent describs your AVRFUCR perin er discromfort on the daye then you had it, ower the last week?

$$
\begin{aligned}
& \begin{array}{lllllllllll}
0 & 0 & 9 & 9 & 9 & 9 & 0 & 0 & 0 & 0 & 0 \\
0 & 1 & 8 & 9 & 4 & 5 & 6 & \frac{1}{8} & 9 & 10
\end{array} \\
& \text { NO PAIN }
\end{aligned}
$$

Driaglims

6. Hew efen have you had a sensation of not emptying your bladdrur conpletely after you finished vrinatiag, over the last week?

C. Nat at all

D. Les than 1 time in

a. Lees than hald the time

3) About half the time

4 Meet than halr the time

2. Armoes dilwaye
6. How eften hare you had to urinate apoin less than twò bours after you finishod urinating. over the last werk? Q. Not at all

$\square_{1}$ Less than 1 time in 6

$a_{0}$ Less than haif the time

a. Abeut halr the time

D. More than balf the time

C) Alromet ahwaya

Irspact of Bompham:

7. Horw mach horn your symptrms kipt yón frum daing tho kinds of thing yor would wesally dn, gere the lant week?

2. None

$\mathbf{D}_{1}$ Quly a litth

2. Some

๑ A lot

8. How much did you thâkl about your symptome, ower the last weels?

D. Nene

U, Only a little

$a_{2}$ Some

d. A let

Quality of Lifo

9. If you were to spend the reot of your tife with your cymptoms jost the way they have been during the last week, bow weuld you foel obout that?

Q. Delighted

D) Pleased

D. Maatly katiafied

D. Miand labout equally entinfied and dissatisfied

$U_{\text {s }}$ Masth diesatisfed

a) Wnhings

Saring the NIH-Chmeic Prostatitis Syaptem Indar Domaine

Pain: Tetal of itama $1 \mathrm{~s}, 1 \mathrm{~b}, 1 \mathrm{~s}, 1 \mathrm{~d}, 2 \mathrm{n}, 2 \mathrm{~b}, 3$, and $4=$

Wrinary Symptems. Total $\alpha$ iteins 5 ard 6.

Quality of Life Impenet: Tatal of items 7,8 and 9 
During this test phase, the instrument was applied twice for each patient. First time was self-administrated and second time, after a time break of one hour, by an oriented medical interview. In this second application, the urologist (C.N.) asked again each question in order to evaluate the understanding of each patient of every item of the instrument and the adequacy of this comprehension to the question intent of the original instrument (NIH-CPSI). This analysis was an evaluation of face validation (15) of final version of the instrument, and determined that the answers of the Brazilian patients really referred to the questions originally proposed by the instrument created by Litwin et al. (9).

The reproducibility of the instrument was evaluated by the coefficient of correlation of Pearson among the answers of the questions of the self-administered questionnaire and those during the interview with the urologist (C.N.) Internal consistency was estimated by the coefficient of $\alpha$ Cronbach, of each domain, D1 (pain and discomfort - items 1-14), D2 (urinary symptoms - items 5-6) and D3 (impact of symptoms on quality of life - items 7-9) in relation to the final score. It was also calculated the coefficient of $\alpha$ Cronbach among all items and final score. SPSS 17-0 software (Statistical Package for Social Sciences) for Windows ${ }^{\circledR}$ was used for statistical analysis.

The research protocol was approved by the Ethical Committee of Research involving Human Beings of the Federal University of Santa Catarina, Brazil (CEPSH-UFSC) \# 2388/12.

\section{RESULTS}

\section{Cross-cultural adaptation}

There were some discrepancies among versions $\mathrm{T} 1, \mathrm{~T} 2, \mathrm{~T} 12, \mathrm{BT} 1$ and $\mathrm{BT} 2$ during the process of cross-cultural adaptation. The nine items of the questionnaire (questions and answers) were re-evaluated in order to solve these differences, and some adequacies were introduced to maintain the original meaning of the questionnaire in a colloquial Brazilian manner. Simple common terms and expressions were used always as possible in order to facilitate the understanding of patients and the use in different socioeconomic and cultural groups of Brazilian population. Some examples of adequacy: "have you experienced any pain or discomfort", is an expression in past participate in English and was translated to simple perfect preterit in Portuguese. Due to these adequacies the back-translations presented some differences but without change of the meaning. Some terms, as "experienced", were translated to common terms in Portuguese, more usual in ordinary language, in order to refer to the original question. Words as "perineum" and "sexual climax" of the original English version were omitted in the Brazilian version, since they are not usual in ordinary Brazilian language, without changing the meaning of the sentences. In the original version, some questions started with an adverbial time adjunct as "in the last week", and others ended with "over the last week", in order to determine the observational time of symptoms throughout one week. The Portuguese version maintained both options but always in the beginning of the sentence in order to facilitate the understanding of the instrument.

\section{Pre-Test}

All 30 patients that answered the pre-final version were male with ages from 18 to 65 years old, median 41.4 years. Eight patients (26.7\%) attended pre-school, nine (30.0\%) high school and 13 (43.3\%) universities. During this phase and also in the others no patient refused to participate in the study.

All items showed a median score of understanding and clarity superior to 8 (Table-1). Worse median (8.7) and the highest standard deviation (1.6) referred to item 3 and it was made an adaptation of the translation in order to improve understanding.

Since all other items were adequate in the pre-test phase, it was obtained the Final Version without any further modifications of the pre-final version, and it was called NIH-CPSI (Braz).

\section{Test}

The reproducibility of NIH-CPSI (Braz) was evaluated comparing the obtained scores of the self-administered version to those of the assisted by a physician, after an interval of one hour. The coefficients of correlation of Pearson, of each item, and the internal consistency of the NIH-CPSI (Braz) evaluated by the coefficient of $\alpha$ Cronbach are shown in Table-2. Face validation evaluation showed that, 
Table 1 - Score of understanding and clarity of items of NIH-CPSI (Braz) during pre-test phase.

\begin{tabular}{lc}
\hline Item & Median \pm standard deviation \\
\hline 1 & $9.27 \pm 0.87$ \\
2 & $9.50 \pm 0.78$ \\
3 & $8.70 \pm 1.60$ \\
4 & $9.03 \pm 1.12$ \\
5 & $9.27 \pm 1.08$ \\
6 & $8.93 \pm 1.36$ \\
7 & $9.20 \pm 1.03$ \\
8 & $9.30 \pm 1.05$ \\
9 & $9.20 \pm 0.85$ \\
\hline
\end{tabular}

although in pre-test phase all items were considered clear (since they obtained an index of clarity and understanding above 8), during the questionnaire assisted by a doctor patients understood poorly item 3. The main reason was that the question in Portuguese induced to misinterpretation of the local of symptoms instead the symptoms itself. After clarifying with Litwin the purpose of the question (personal contact) we changed the version to "how often do you present any of the symptoms of questions 1 and 2".

So, the final version of NIH-CPSI (Braz) included a modification after the pre-test phase, in order to reassure the face validation of the instrument. After this last modification (item 3), the questionnaire was again applied to 30 patients that attended the Urologic Departament of UFSC with pain or perineal or ejaculatory discomfort in order to verify the clarity and understanding as was done in the pre-test phase. Median score given by the patients was 9.06 and standard deviation 1.08. The item was clear (with a superior score than obtained in pre-test phase) and the validation of the instrument was adequate. So it was proposed the Brazilian version of NIH-CPSI, called NIH-CPSI (Braz), or Indice de Sintomas da Prostatite Crônica (Figure-2). That version was submitted to the original authors and they considered it adequate.

\section{DISCUSSION}

Questionnaires for clinical evaluation of subjective symptoms, that transform them in objective measures, are more frequent and are be-

Table 2 - Reproducibility and internal consistency of NIH-CPSI (Braz).

\begin{tabular}{|c|c|c|c|c|c|}
\hline \multirow[t]{2}{*}{ Domain (score scale) } & \multirow[t]{2}{*}{ Item } & \multicolumn{2}{|c|}{ Median (IC 95\%) } & \multirow[t]{2}{*}{ Correlation } & \multirow[t]{2}{*}{$\alpha$} \\
\hline & & $\mathrm{T} 1$ & T2 & & \\
\hline Pain localization (0-6) & 1.2 & $1.8(1.4-2.2)$ & $1.9(1.5-2.3)$ & 0.91 & \\
\hline Pain frequence $(0-5)$ & 3 & $2.3(1.8-2.7)$ & $2.4(2.0-2.8)$ & 0.89 & \\
\hline Pain intensity $(0-10)$ & 4 & $3.8(2.8-4.8)$ & $4.1(3.2-5.0)$ & 0.94 & \\
\hline Domain: pain (0-21) & $1-4$ & $7.9(6.3-9.4)$ & $8.4(7.0-9.8)$ & 0.92 & 0.90 \\
\hline Domain: Urinary symptoms $(0-10)$ & 5.6 & $3.8(2.4-5.2)$ & $3.8(2.4-5.2)$ & 0.99 & 0.85 \\
\hline Impact (0-6) & 7.8 & $2.6(1.9-3.2)$ & $2.5(1.9-3.1)$ & 0.96 & \\
\hline Quality of life $(0-6)$ & 9 & $3.6(2.9-4.2)$ & $3.5(2.9-4.2)$ & 0.96 & \\
\hline Domain: impact on quality of life $(0-12)$ & $7-9$ & $6.1(4.9-7.4)$ & $6.0(4.9-7.1)$ & 0.97 & 0.93 \\
\hline
\end{tabular}

Results obtained after application and reapplication of NIH-CPSI (Braz) in 30 patients. Correlation evaluated using (p) Pearson coefficient. $=\alpha$ Cronbach coefficient 
Figure 2 - Brazilian version of the National Institutes of Health Chronic Prostatits Symptom Index, called NIH-CPSI (Braz).

$$
\text { NIH - CHRONIC PROSTATITIS SYMPTOM INDEX (BRAZ) / (ÍNDICE DE SINTOMAS DA PROSTATITE CRÔNICA) }
$$

\footnotetext{
Dor ou Desconforto

1. Na última semana, você sentiu alguma dor ou desconforto nas seguintes áreas?

a. Entre 0 ânus e os testículos

b. Testículos

c. Na ponta do pênis (Não relacionadacom 0 ato de urinar)

d. Na área abaixo da cintura (região púbica ou área da bexiga)

$$
\begin{array}{cc}
\operatorname{Sim} & \text { Não } \\
\square_{1} & \square_{0} \\
\square_{1} & \square_{0} \\
\square_{1} & \square_{0} \\
\square_{1} & \square_{0}
\end{array}
$$

2. Na última semana, você sentiu:

$\begin{array}{lr}\text { a. Dor ou queimação ao urinar? } & \text { Sim Não } \\ \text { b. Dor ou desconforto durante } & \square_{1} \quad \square_{0} \\ \text { ou após a ejaculação? } & \\ & \square_{1} \quad \square_{0}\end{array}$

3. Com que frequência você apresentou algum dos sintomas relacionados às questões 1 e 2 ?

$\square$ Nunca

$\square$ Raramente

$\square_{2}$ Algumas vezes

$\square_{3}$ Frequentemente

$\square_{4}$ Quase sempre

$\square_{5}$ Sempre
}

4. Durante a última semana, que número melhor descreve sua dor ou desconforto MÉDIO, sendo zero nenhuma dor e 10 a pior dor que você possa imaginar.

$$
\begin{array}{lr}
\square_{0} \square_{1} \square_{2} \square_{3} \square_{4} \square_{5} \square_{6} \square_{7} \square_{8} \square_{9} \square_{10} \\
\text { NENHUMA } & \text { A PIOR } \\
\text { DOR } & \text { DOR QUE } \\
& \text { VOCÊ POSSA } \\
& \text { IMAGINAR }
\end{array}
$$

\section{Micçãa}

5. Durante a última semana, com que frequência você teve a sensação de não esvaziar completamente a bexiga depois de terminar de urinar?

$\square_{0}$ Nenhuma vez

$\square$ Menos de 1 em 5 vezes

$\square$, Menos de metade das vezes

$\square_{3}$ Metade das vezes

$\square_{4}$ Mais de metade das vezes

$\square_{5}$ Quase sempre

6. Durante a última semana, com que frequência você teve que urinar de novo antes de completar duas horas de ter urinado?

$\square$ Nenhuma vez

$\square_{1}$ Menos de 1 em 5 vezes

$\square_{2}$ Menos de metade das vezes

$\square_{3}$ Metade das vezes

$\square_{4} \quad$ Mais de metade das vezes

$\square_{5}$ Quase sempre

\section{Impacto dos Sintomas}

7. Na última semana, até que ponto os sintomas o impediram de fazer as coisas que você normalmente faz?

$\square_{0} \mathrm{Nada}$

$\square$, Apenas um pouco

$\square_{2}$ Algumas vezes

$\square_{3}$ Muito

9. Na última semana, quanto você pensou sobre seus sintomas? $\square_{0} \mathrm{Nada}$

$\square$ Apenas um pouco

$\square$, Algumas vezes

$\square_{3}$ Muito

\section{Qualidade de Vida}

10. Se você passasse o resto da sua vida com os sintomas que sentiu durante a última semana, como você se sentiria?

$\square_{0}$ Contente

$\square_{1}$ Satisfeito

$\square_{2}$ Geralmente satisfeito

$\square_{3}$ Igualmente satisfeito e insatisfeito

$\square_{4}$ Geralmente insatisfeito

$\square_{5}$ Infeliz

$\square_{6}$ Péssimo

Índice final $=\ldots$ (soma dos escores dos 3 domínios)

Dor: Total dos itens 1a, 1b, 1c, 1d, 2a, $2 b, 3$ e 4

Sintomas Urinários: Total dos

itens 5 e 6

Impacto sobre Qualidade de Vida:

Total dos itens 7, 8, e 9

$=$

$=$

$=$ 
coming essential in clinical practice, mainly in scientific researches (19). Such instruments, adequately proposed and validated scientifically, are useful tools for diagnosis and grading of symptoms. Both diagnostic and symptomatic evaluation questionnaires, when validated to different cultures, homogenize scores, allowing comparisons in different places, and different languages and cultures.

In order to use these instruments in different places, cultures and languages than originally proposed, it is necessary to submit them to cross-cultural adaptation. This process involves translation and adaptation to the target culture; only a diligent process maintains equivalent measures and this process must be reliable. This is why we choose to follow the guidelines of Beaton et al. (19) that include translation, synthesis, back-translation, panel of specialists' evaluation, pre-test and evaluation by the original authors.

After the process of adaptation, we proceeded to validate the instrument, evaluating its psychometric proprieties. During validation we evaluated reproducibility, internal consistency and face validation. The reproducibility of the original instrument, described by Litwin et al., was made by comparison of answers of the self-applied questionnaire in two different moments, with an interval or two weeks (9). During validation of the Brazilian version, the reproducibility was made by correlating the answers of self-applied questionnaire to those of the medical assisted questionnaire. We decided not to submit the questionnaire twice (self-application) in order to avoid repeated errors of interpretation. The same error, in both moments, would indicate a good correlation and good reproducibility of the instrument, but without validation. When applying the instrument during a medical interview, it was possible to verify the face validation.

Internal consistency, evaluated by the coefficient of $\alpha$ Cronbach, was made in the same way than in the original work of Litwin et al. (9). The Brazilian version showed a coefficient of $\alpha=0.90$; 0.85 and 0.83 of domains D1, D2 and D3 and final score, respectively. In the original questionnaire the coefficient of $\alpha$ Cronbach of the same comparisons was $0.86 ; 0.79$ and 0.87 . The coefficient of $\alpha$ Cronbach among all nine individual items and final score was 0.85 in the Brazilian version and 0.86 in the original version. The reproducibility of 9 items of the Brazilian version, using the correlation coefficient of Person, showed values from 0.89 to 0.90 . The original instrument showed coefficients from 0.83 to 0.93 (9). In conclusion, the reproducibility and internal consistency of NIH-CPSI (Braz) were similar to the results of the original questionnaire. Other cross-cultural adaptations of NIH-NCSI showed similar results. For example, the Japanese version showed a reproducibility coefficient from 0.63-0.91 (11). The $\alpha$ Cronbach coefficient varied from 0.83 to 0.87 in the Japanese version and from 0.60 to 0.74 in the German version (12).

The main difference of the Brazilian version from the original NIH-CPSI was related to item 3. If the same translated sentence had been used in the process of cross-cultural adaptation, the answers would be related only to the symptoms of item 1. After talking to the original author, it was clarified that the item 3 should address the symptoms of items 1 and 2 and the question was reformulate in order to be equivalent to the original instrument.

Only patients with prostatitis symptoms were included in the study. The ability of the questionnaire to discriminate symptoms of $\mathrm{CP} /$ CPPS from other genitourinary diseases or even asymptomatic patients was well established in several studies $(11,16)$. Items 5 and 6 , of the urinary symptoms domains, are very similar to questions 1 and 2 of the IPSS (International Prostate Symptom Score) (20), except in relation of time (during last week in NIH-CPSI instead of last month in I-PSS) and represent bladder symptoms of voiding and storage, respectively.

NIH-CPSI is not intended to be a diagnostic tool of prostatitis, since it is a self-administered questionnaire to patients. Clinical evaluation by an urologist must not be waived for the correct diagnosis. It is recommended the use of NIH-CPSI for grading of symptoms in patients with a clinical diagnosis of prostatitis (18). But it was also used as reference in several population studies of prevalence and incidence of symptoms of prostatitis, by self-application or during medical interviews (21-24). 
The final result of the present work, the Brazilian version called NIH-CPSI (Braz) presented in Figure-2 (Indice de Sintomas da Prostatite Crônica) will allow the development in our country of clinical studies of patients with symptoms of CP/CPPS similar to those already performed in different cultures, with comparable results internationally. It will help us establish an epidemiological profile of Brazilian patients and determine the prevalence of these symptoms. It can be used as a complementary tool in clinical practice similar to I-PSS (20), used for the evaluation of benign prostatic hyperplasia.

\section{ACKNOWLEDGMENTS}

To Dr. Mark Litwin, that kindly allowed the elaboration of the Brazilian version of NIH-CPSI.

To Mr. Arno Blass, retired professor of UFSC, native Brazilian spoken non-medical translator.

To Mr. Eugene Nelson and Mrs. Sandy Reyes, native English translators, who performed the back-translation from Portuguese to English.

To the patients who answered the questionnaires.

\section{CONFLICT OF INTEREST}

None declared.

\section{REFERENCES}

1. Collins MM, Stafford RS, O'Leary MP, Barry MJ: How common is prostatitis? A national survey of physician visits. $J$ Urol. 1998; 159: 1224-8.

2. Krieger JN, Nyberg L Jr, Nickel JC: NIH consensus definition and classification of prostatitis. JAMA. 1999; 282: 236-7.

3. Krieger JN, Lee SW, Jeon J, Cheah PY, Liong ML, Riley DE: Epidemiology of prostatitis. Int J Antimicrob Agents. 2008; 31(Suppl 1): S85-90.

4. Meares EM, Stamey TA: Bacteriologic localization patterns in bacterial prostatitis and urethritis. Invest Urol. 1968; 5: 492-518.

5. Sharp VJ, Takacs EB, Powell CR: Prostatitis: diagnosis and treatment. Am Fam Physician. 2010; 82: 397-406.

6. McNaughton Collins M, Fowler FJ Jr, Elliott DB, Albertsen PC, Barry MJ: Diagnosing and treating chronic prostatitis: do urologists use the four-glass test? Urology. 2000; 55: 403-7.
7. Neal DE Jr, Moon TD: Use of terazosin in prostatodynia and validation of a symptom score questionnaire. Urology. 1994; 43: 460-5.

8. Nickel JC, Sorensen R: Transurethral microwave thermotherapy for nonbacterial prostatitis: a randomized double-blind sham controlled study usingnew prostatitis specific assessment questionnaires. J Urol. 1996; 155: 1950-4; discussion 1954-5.

9. Litwin MS, McNaughton-Collins M, Fowler FJ Jr, Nickel JC, Calhoun EA, Pontari MA, et al.: The National Institutes of Health chronic prostatitis symptom index: development and validation of a new outcome measure.Chronic Prostatitis Collaborative Research Network. J Urol. 1999; 162: 369-75.

10. Collins MM, O'Leary MP, Calhoun EA, Pontari MA, Adler A, Eremenco S, et al.: The Spanish National Institutes of HealthChronic Prostatitis Symptom Index: translation and linguistic validation. J Urol. 2001; 166: 1800-3.

11. Kunishima Y, Matsukawa M, Takahashi S, Itoh N, Hirose T, Furuya S, et al.: National institutes of Health Chronic Prostatitis Symptom Index for Japanese men. Urology. 2002; 60: 74-7.

12. Hochreiter W, Ludwig M, Weidner W, Wagenlehner F, Naber K, Eremenco S, et al.: National Institutes of Health (NIH) Chronic Prostatitis Symptom Index. The German version. Urologe $A$. 2001; 40: 16-7.

13. Giubilei G, Mondaini N, Crisci A, Raugei A, Lombardi G, Travaglini F, et al.: The Italian version of the National Institutes of Health Chronic Prostatitis Symptom Index. Eur Urol. 2005; 47: 805-11.

14. Korrovits P, Punab M, Mehik A, Mändar R: The Estonian version of the National Institutes of Health chronic prostatitis symptom index. Andrologia. 2006; 38: 106-9.

15. Cheah PY, Liong ML, Yuen KH, Lee S, Yang JR, Teh CL, et al.: Reliability and validity of the National Institutes of Health: Chronic Prostatitis Symptom Index in a Malaysian population. World J Urol. 2006; 24: 79-87.

16. Leskinen MJ, Mehik A, Sarpola A, Tammela TL, Järvelin MR: The Finnish version of The National Institutes Of Health Chronic Prostatitis Symptom Index correlates well with the visualpain scale: translation and results of a modified linguistic validation study. BJU Int. 2003; 92: 251-6.

17. Karakiewicz PI, Perrotte P, Valiquette L, Benard F, McCormack $\mathrm{M}$, Menard C, et al.: French-Canadian linguistic validation of the NIH Chronic Prostatitis Symptom Index. Can J Urol. 2005; 12: 2816-23.

18. Roberts R0, Jacobson DJ, Girman CJ, Rhodes T, Lieber MM, Jacobsen SJ: Low agreement between previous physician diagnosed prostatitis and national institutes of health chronic prostatitis symptom index pain measures. J Urol. 2004; 171: 279-83.

19. Beaton DE, Bombardier C, Guillemin F, Ferraz MB: Guidelines for the process of cross-cultural adaptation of self-report measures. Spine (Phila Pa 1976). 2000; 25: 3186-91. 
20. Barry MJ, Fowler FJ Jr, O'Leary MP, Bruskewitz RC, Holtgrewe HL, Mebust WK, et al.: The American Urological Association symptom index for benign prostatic hyperplasia. The Measurement Committee of theAmerican Urological Association. J Urol. 1992; 148: 1549-57; discussion 1564.

21. Nickel JC, Downey J, Hunter D, Clark J: Prevalence of prostatitis-like symptoms in a population based study using the National Institutes of Health chronic prostatitissymptom index. J Urol. 2001; 165: 842-5.

22. Kunishima $\mathrm{Y}$, Mori M, Kitamura $\mathrm{H}$, Satoh $\mathrm{H}$, Tsukamoto T: Prevalence of prostatitis-like symptoms in Japanese men: Population-based study in a town in Hokkaido. Int J Urol. 2006; 13: 1286-9.

23. Ejike CE, Ezeanyika LU: Prevalence of chronic prostatitis symptoms in a randomly surveyed adult population of urban-community-dwelling Nigerianmales. Int J Urol. 2008; 15: 340-3.
24. Bartoletti R, Cai T, Mondaini N, Dinelli N, Pinzi N, Pavone C, et al.: Prevalence, incidence estimation, risk factors and characterization of chronic prostatitis/chronic pelvic pain syndrome in urological hospital outpatients in Italy: results of a multicenter case-control observational study. J Urol. 2007; 178: 2411-5; discussion 2415.

\section{Correspondence address:}

Cristiano Novotny, MD

Rua Apeninos, 114 / 401

Córrego Grande. Florianópolis, SC, 88037-620, Brazil

Telephone: + 5548 9115-0555 